\title{
Unusual transmitral Doppler filling profile induced by right ventricular pacing
}

\author{
Hammam Shereef, ${ }^{1}$ Ahmed Subahi $\left(10,{ }^{2}\right.$ Mohit Pahuja, ${ }^{2}$ Luis Afonso ${ }^{2}$
}

${ }^{1}$ Internal Medicine, Beaumont Hospital Dearborn, Dearborn, Michigan, USA

${ }^{2}$ Division of Cardiology, Wayne State University/Detroit Medical Center, Detroit, Michigan, USA

\section{Correspondence to Dr Ahmed Subahi; asubahi@med.wayne.edu}

Accepted 13 March 2021

\section{Check for updates}

(c) BMJ Publishing Group Limited 2021. No commercial re-use. See rights and permissions. Published by BMJ.

To cite: Shereef $H$, Subahi $A$, Pahuja M, et al. BMJ Case Rep 2021;14:e242539. doi:10.1136/bcr-2021242539

\section{DESCRIPTION}

An 81-year-old man with a history of complete heart block with a dual-chamber pacemaker was referred to our centre with a suspicion of device malfunction. Device interrogation revealed a normal function with a $79 \%$ pacing rate. Continuous-wave (CW) Doppler across mitral inflow revealed a 'triphasic' flow pattern comprising prominent isovolumic relaxation flow (IVRF) signals (figure 1A, green arrows). The IVRF signal is not appreciated with native beats (yellow arrow). Sequential still frameby-frame analysis of a contrast-enhanced fourchamber view, beginning with left ventricular (LV) early diastole (figure 1B, panels 1 and 2 , see red arrowheads for timing of cardiac cycle), showed early relaxation of the apical segments (panel 3), followed by a wavefront of relaxation progressing to the mid-ventricular (panels 4 and 5) and finally basal segments (figure 1B, panel 6). Pulsed-wave Doppler interrogation at the mitral tips was showing a normal biphasic flow pattern (discrete $\mathrm{E}$ and $\mathrm{A}$ waves) compared with the triphasic flow pattern observed with CW Doppler (figure 1C, top panel). Colour M-mode Doppler showed a prominent apically directed IVRF before mitral valve opening (demarcated by solid yellow line) that is seen blending with early filling (transvalvular) flow,

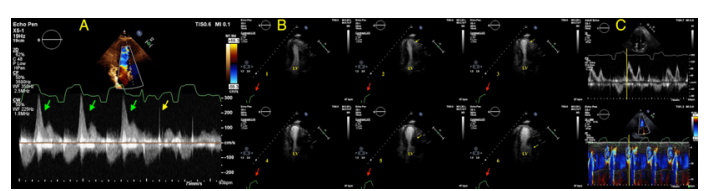

Figure 1 (A) Continuous-wave Doppler trace across mitral inflow showing a 'triphasic' flow pattern comprising prominent isovolumic relaxation flow signals (green arrows). The isovolumic relaxation flow signal is not appreciated with native beats (yellow arrow). (B) Sequential still frame-by-frame analysis of a contrastenhanced four-chamber view, beginning with early diastole (panels 1 and 2, see red arrowheads for the timing of cardiac cycle). Note early relaxation of the apical segments (panel 3), followed by a wave front of relaxation progressing to the mid-ventricular (panels 4 and 5) and finally basal segments (panel 6). (C) Top panel: pulsed-wave Doppler interrogation at the mitral tips, showing normal biphasic flow pattern (discrete $\mathrm{E}$ and a waves) compared with the triphasic flow pattern observed with continuous-wave Doppler. Bottom panel: colour M-mode Doppler depicting prominent apically directed isovolumic relaxation flow before mitral valve opening (demarcated by the solid yellow line) that is seen blending with early filling (transvalvular) flow, right after mitral valve opening. LV, left ventricle.

\section{Learning points}

- Prominent isovolumic relaxation flow observed with paced beats could be misinterpreted as flow occurring across the mitral valve inflow, based on the continuous-wave Doppler trace alone.

- Our case highlights the need for echocardiographers to recognise prominent isovolumic relaxation flow and avoid mistaking it for a more widely recognised triphasic flow pattern seen in individuals with diastolic dysfunction (mitral L wave) or tracing over it, which could lead to an overestimation of the transmitral gradient.

right after mitral valve opening (figure 1C, bottom panel). The prominent IVRF observed in our patient could be attributed to an intraventricular pressure gradient caused by LV apical early relaxation due to dyssynchronous LV apex to base contractionrelaxation in patients with right ventricular pacing. However, similar phenomenon has been observed in several conditions, including aortic valve disease, rheumatic heart disease, hypertrophic cardiomyopathy, hypertension, ventricular pre-excitation, coronary artery disease, chronic renal failure and right ventricular pacing, and even in healthy individuals. ${ }^{1-5}$ Furthermore, IVRF can be apically directed, basally directed or bidirectional, occurring during the isovolumic relaxation period. ${ }^{2}$

Contributors HS wrote the case description. AS prepared the figure and checked grammar. MP performed the echocardiogram and prepared the figure. LA was involved in final revision by the consultant.

Funding The authors have not declared a specific grant for this research from any funding agency in the public, commercial or not-for-profit sectors.

Competing interests None declared.

Patient consent for publication Obtained.

Provenance and peer review Not commissioned; externally peer reviewed.

ORCID iD

Ahmed Subahi http://orcid.org/0000-0003-0384-4164

\section{REFERENCES}

1 Sasson Z, Hatle L, Appleton CP, et al. Intraventricular flow during isovolumic relaxation: description and characterization by Doppler echocardiography. J Am Coll Cardiol 1987;10:539-46.

2 Zhang H, Ren X, Song J, et al. Intraventricular isovolumic relaxation flow patterns studied by using vector flow mapping. Echocardiography 2016;33:902-9. 
3 Price RW, Moody JM, Rubal BJ, et al. Intraventricular flow during isovolumic relaxation: comparison of normal and paced ectopic excitation under varied loading conditions. Echocardiography 1996;13:57-64.

4 Lin M-S, Lin J-L, Liu Y-B, et al. Immediate impairment of left ventricular mechanical performance and force-frequency relation by rate-responsive dual-chamber, but not atrial pacing: implications from intraventricular isovolumic relaxation flow. Int J Cardiol 2006;109:367-74.

5 Salahuddin S, Bhargava B. Unusual Doppler trace in mitral stenosis: prominent isovolumic relaxation flow. Heart 2012:98:172.

Copyright 2021 BMJ Publishing Group. All rights reserved. For permission to reuse any of this content visit

https://www.bmi.com/company/products-services/rights-and-licensing/permissions/

BMJ Case Report Fellows may re-use this article for personal use and teaching without any further permission.

Become a Fellow of BMJ Case Reports today and you can:

- Submit as many cases as you like

Enjoy fast sympathetic peer review and rapid publication of accepted articles

Access all the published articles

Re-use any of the published material for personal use and teaching without further permission

\section{Customer Service}

If you have any further queries about your subscription, please contact our customer services team on +44 (0) 2071111105 or via email at support@bmj.com.

Visit casereports.bmj.com for more articles like this and to become a Fellow 